\title{
DIREITOS SÓCIO-AMBIENTAIS: APONTAMENTOS POLÊMICOS ACERCA DO PROJETO AQÜÍFERO GUARANI, MAIOR LENÇOL DE ÁGUA DO MUNDO, LOCALIZADO NA AMÉRICA DO SUL
}

\author{
José Augusto Guterres \\ Advogado, pós-graduando em Direito Ambiental pela Universidade Federal de Santa Catarina \\ e-mail: guterresadv@hotmail.com.
}

RESUMO: O acesso à água é direito fundamental de todos. Em si considerada, ou como recurso hídrico, é, inegavelmente, pressuposto para existência de vida na Terra e imprescindível para a existência digna do ser humano. O Aqüífero Guarani enquadra-se no conceito de águas subterrâneas transfronteiriças, já que se localiza sob o Brasil, Argentina, Paraguai e Uruguai, devendo ser estudado conjuntamente pelo Direito Ambiental e Internacional. Dada sua magnitude, configura-se numa das principais reservas de água do mundo, carecendo, portanto, de proteção internacional. Ademais, é um agente incrivelmente potencializador da emancipação latinoamericana, cabendo, portanto, uma análise pormenorizada do projeto que the está sendo implementado, haja vista que claramente aspectos políticos e sociais estão sendo postos em segundo plano, em benefício de interesses privados e estrangeiros.

PALAVRAS-CHAVE: Direitos Fundamentais. Acesso à Água. América Latina. Aqüífero Gurani. Direito Ambiental e Internacional. Políticas Públicas. Privatização da Água. 


\section{DESCRIÇÃO DO AQÜÍFERO GUARANI}

Segundo Fabiana Paschoal de Freitas", o termo "Aqüífero Guarani" foi a denominação formal e unificadora atribuída a este manancial em 1.994 pelo geólogo uruguaio Danilo ANTON em homenagem à população indígena que ali habitava nos primórdios da colonização, sendo que outrora fora chamado de Aqǘfero Gigante do Mercosul - por ocorrer nos Estados-membros do referido acordo comercial - e conhecido pelos nomes Botucatu, no Brasil, Misiones, no Paraguai, e Tacuerambó, no Uruguai e Argentina. O nome Botucatu, por vezes, é ainda utilizado no Brasil, sobretudo na região de São Paulo, vale dizer.

Cumpre definir, de início, que "são consideradas subterrâneas todas as águas situadas abaixo da superfície da Terra", e que as águas subterrâneas transfronteiriças são aquelas "situadas abaixo da superfície terrestre que ultrapassem as fronteiras nacionais de um determinado país, ocorrendo no território de dois ou mais Estados"3

Com efeito, o Aqüífero Guarani possui uma extensão total de cerca de 1,2 milhões de $\mathrm{km}^{2}$, numa área de incidência de quatro países, distribuindo-se, assim, em: $840.000 \mathrm{~km}^{2}$ no Brasil; $225.500 \mathrm{~km}^{2}$ na Argentina; $71.700 \mathrm{~km}^{2}$ no Paraguai; e $58.000 \mathrm{~km}^{2}$ no Uruguai. ${ }^{4}$ Para se ter uma melhor noção da grandeza de sua área de incidência, ela é maior que os territórios da França, Portugal e Espanha juntos. ${ }^{5}$

Quanto à sua característica transfronteiriça, não se pode perder de vista que o Aqǘf́fero Guarani enquadra-se no conceito de Bacia de Drenagem Internacional ${ }^{6}$, o qual deve ser levado em consideração porque abrange além do sistema de águas

${ }^{1}$ FREITAS, Fabiana Paschoal de. Águas subterrâneas transfronteiriças: o Aqüífero Guarani e o Projeto do GEF/Banco Mundial. In: BENJAMIN, Antonio Herman (Org.). Direito, água e vida. São Paulo: Imprensa Oficial, 2.003. 2 v. p 159.

${ }^{2}$ HEATH, Ralph C. Hidrologia básica de água subterrânea.

${ }^{3}$ FREITAS, Fabiana Paschoal. Op. cit. p.162.

4 Ibidem.

${ }^{5}$ Revista CREA-PR, p. 16, fev/mar. 2.003.

${ }^{6}$ Bacia de drenagem internacional é uma área geográfica que cobre dois ou mais Estados, determinada pelos limites fixados por divisores de água, inclusive as águas de superfície e as subterrâneas, que desembocam num ponto comum. 
que se constitui através de uma relação física, também o ciclo hidrológico de determinado sistema.

No Brasil, é albergado por oito estados, quais sejam, em ordem da maior para a menor extensão, o Mato Grosso do Sul, Rio Grande do Sul, São Paulo, Paraná, Goiás, Minas Gerais, Santa Catarina, e Mato Grosso.

Gerôncio Albuquerque ROCHA explica que "o Aqüífero Guarani é um pacote de camadas arenosas que se depositaram na bacia sedimentar do Paraná (...) entre 200 e 132 milhões de anos (...)".7

Uma das maiores vantagens das águas subterrâneas presentes em aqüíferos em geral, incluindo-se o Guarani, é que elas passam naturalmente por um processo de depuração, ou seja, limpeza/filtragem da água, quando de sua captação. Sua ocorrência subterrânea não significa, exatamente, a existência de um rio ou lago subterrâneo. Denis Russo BUGIERMAN fala em "uma espécie de esponja rochosa", ou seja, "uma vasta camada de pedra porosa encharcada de água".

As águas do Aqüífero Guarani, portanto, ocorrem preenchendo seus espaços, ou seja, os poros e fissuras das rochas que o formam. ${ }^{9}$

O Aqüífero Guarani ocupa profundidades variadas, entre 50 e 1.500 metros, sendo que contém algo em torno de 45 trilhões de metros cúbicos de água, a qual figura entre as mais puras do planeta. $^{10}$

Diante de tais dimensões, não resta dúvida da importância do Aqüífero Guarani para os países a ele sobrejacentes e para o mundo.

Por fim, vale lembrar que ainda não existem técnicas suficientemente eficazes para descontaminação de aqüíferos. Daniela CARIDE alerta para o fato de que "muitos poços estão poluindo lençóis subterrâneos. E estes demoram alguns

${ }^{7}$ ROCHA, Gerôncio Albuquerque. O grande manancial do Cone Sul. In: Revista Estudos Avançados, n³0. São Paulo: Instituto de Estudos Avançados/USP, 1. 997. 11v. p. 192.

${ }^{8}$ BUGIERMAN, Denis Russo. Tem uma esponja aqui dentro. Super Interessante, ano $13, n^{\circ} 7$. São Paulo: Abril, 1.999. p. 65

${ }^{9}$ FREITAS, op.cit. p. 163.

${ }^{10}$ Agência Nacional de Águas. Disponível em: <http://www.ana.gov.br> 
milhares de anos para serem despoluídos. Os mananciais não são como os rios, que em 15 a 20 dias se renovam". ${ }^{11}$

Não resta dúvida, portanto, que a melhor forma de proteger o Aqüífero Guarani é através de ações preventivas, usando-o de forma compatível aos princípios da precaução e da sustentabilidade, haja vista a grave ameaça ao meio ambiente (incluindo-se, assim, a população humana) que a poluição de um aqüífero de tão grandes proporções representa.

\section{PROJETO DE PROTEÇÃO AMBIENTAL E GESTÃO SUSTENTÁVEL INTEGRADA DO SISTEMA AQÜÍFERO GUARANI}

\subsection{Síntese - Pontos Fundamentais}

Configurando-se o Aqüífero Guarani como a maior reserva de água potável do mundo, e sendo esta escassa, já que é grande a demanda prevista para os próximos anos, e sua deterioração se mostrando crescente, urge a elaboração de mecanismos para mudança desse quadro.

Tais fatos foram as principais alegações para a elaboração e implementação do Projeto de Proteção Ambiental e Gerenciamento Sustentável Integrado do Sistema Aqüífero Guarani, cujo principal objetivo é, segundo a Agência Nacional de Águas - ANA, "contribuir para a superação da situação atual por meio da formulação de um modelo técnico, legal, e institucional para a gestão dos recursos do Aqüífero de forma coordenada pelo conjunto dos países e organismos envolvidos". ${ }^{12}$

De fato, as características físicas do Aqüífero, tais como dimensões, espessuras e profundidades, encontram-se hoje razoavelmente conhecidas. Todavia nota-se a carência de um sistema unificado de outros conhecimentos acerca do Aqüífero Guarani, o que, se existisse, seria um bom instrumento para uma utilização sustentável do mesmo. Rocha trata desse assunto ao afirmar que o nível de conhecimento do Aqüífero em toda a bacia "é ainda fragmentado e insuficiente, com

11 CARIDE, Daniela. Legislação ignora exploração subterrânea. Relatório da Gazeta Mercantil, 19/11/1.998, p. 06.

12 BRASIL. Agência Nacional de Águas (ANA). Sítio oficial na internet. Disponível em: $<$ <ttp://www.ana.gov.br> 
cerca de 20 anos de atraso em relação ao primeiro surto exploratório de águas". ${ }^{13} \mathrm{~A}$ criação de um sistema unificado de informações sobre o Aqüífero Guarani, um dos objetivos iniciais do Projeto, é, portanto, um importante passo para sua conservação.

O marco inicial do Projeto, quando os Governos da Argentina, Brasil, Paraguai e Uruguai aprovaram seu documento conceitual, foi uma reunião em Foz do Iguaçu, realizada em janeiro de 2000, com subsídios do Governo brasileiro, através da Secretaria de Recursos Hídricos do Ministério do Meio Ambiente SRH/MMA.

São beneficiários, então, Argentina, Brasil, Paraguai e Uruguai, dos recursos de doação que advém do Global Environment Facillity - GEF (Fundo para o Meio Ambiente Mundial), cuja agência implementadora é o Banco Mundial.

Outros organismos internacionais que participam do Projeto são a Organização dos Estados Americanos - OEA, tida como a executora internacional, a Agência Internacional de Energia Atômica - AIEA, o Programa de Cooperação do Governo do Paraguai - PY, o Serviço Geológico da Alemanha - BGR, o Programa de Recursos Hídricos do Banco Mundial e o Governo do Reino dos Países Baixos BNWPP. Nacionalmente, é a Agência Nacional de Águas a implementadora do Projeto, sendo que é a Secretaria de Recursos Hídricos do Ministério do Meio Ambiente (SRH/MMA) o órgão responsável pelo Projeto no Brasil.

O resultado geral esperado ao final da execução é que os quatro países disponham de um bom modelo de gestão para o Sistema Aqüífero Guarani.

Em suma, este é o projeto que já está em vigor. É imprescindível, todavia, perpassá-lo por um juízo de valor, analisando quais são os reais interesses por trás de sua implementação e, o que é mais importante, se os povos de fato possuem alguma possibilidade de auferir algum benefício disso tudo, mencionando-se de antemão que é possível notar quanto a este assunto uma completa despolitização, vale dizer, a exclusão dos necessários debates sociais em torno dele.

\footnotetext{
${ }^{13}$ ROCHA, op.cit. p. 198.
} 


\subsection{QUESTÕES POLÊMICAS SOBRE O PROJETO DE PROTEÇÃO E GESTÃo SUSTENTÁVEL INTEGRADA DO SISTEMA AQÜÍFERO GUARANI}

Um projeto como este abordado acima é, inegavelmente, válido e necessário. Uma reserva de águas das proporções do Aqüífero Guarani não pode, nos dias correntes, ser explorada sem um minucioso plano de gestão.

Louvável, portanto, a iniciativa dos quatro países cujos territórios encontramse logo acima do Aqüífero em elaborar e implementar o Projeto de Proteção e Gestão Sustentável do Sistema Aqüífero Guarani. Da mesma forma, louvável e importante, a ajuda técnica e financeira que outros países e organizações, nacionais e internacionais, vêm prestando para que tal projeto seja efetivado.

Todavia o Projeto Aqüífero Guarani não vem passando incólume de críticas desde que foi criado. Na verdade, bradam-se cada vez mais vozes contrárias à sua execução. Tal não se dá, logicamente, por causa dos objetivos oficiais, que são sua proteção e gestão sustentável, mas porque muitos entendem que, por trás do véu do Projeto, adormecem escusos interesses.

É importante destacar que, embora haja muitas críticas e denúncias infundadas a respeito de uma "compra" do Aqüífero Guarani, muitos são os estudiosos e gabaritados profissionais que adotam uma postura extremamente cautelosa quando o assunto é o envolvimento de capital internacional a patrocinar estudos e exploração das riquezas naturais brasileiras.

Para fundamentar este receio, basta citar a conhecida biopirataria que empresas multinacionais reiteradamente vêm promovendo em solo brasileiro, principalmente na Amazônia, assim como a rápida difusão da lavoura de produtos geneticamente modificados, os quais, por apresentarem maior rentabilidade em curto tempo, foram ilegalmente plantados em enorme quantidade (e posteriormente tiveram o aval do Governo brasileiro) ainda antes de se exaurirem estudos que comprovassem que tais produtos não são capazes de ofender a saúde humana ou o 
meio ambiente, em cristalina afronta ao princípio de Direito Ambiental da precaução. $^{14}$

\subsubsection{Despolitização do Debate acerca do Projeto de Proteção e Gestão Sustentável Integrada do Sistema Aqüífero Guarani}

Quanto ao Aqüífero Guarani, há questões que Ihe são peculiares, visto que por muitos anos fora objeto de pesquisa de Universidades locais, que, com o advento do Projeto, passaram a ter uma importância secundária em seu estudo e desenvolvimento. Atrelado a este, outro ponto bastante criticado é a falta de participação da sociedade civil e a conseqüente despolitização da gestão do Aqüífero Guarani. Além disso, cresce mundialmente a tendência da mercantilização da água, que em vários países já se encontra sob o domínio de instituições privadas.

Diz-se, assim, que o conhecimento adquirido durante anos através de pesquisas das Universidades latino-americanas pode vir a ser dominado por grandes grupos econômicos e corporações transnacionais ${ }^{15}$, e também que, "da mesma maneira que a questão da ALCA, não existe nenhuma participação da população destes países no manejo desta informação, no controle e, muito menos, na tomada das decisões a respeito. ${ }^{16 "}$

Com efeito, a participação popular, embora oficialmente prevista no Projeto, tem sido ínfima e por provocação tão só de entidades civis sem vínculo com o Projeto, e, portanto, sem possibilidade de intervenção no mesmo. A divulgação da importância do Aqüífero e do andamento de seu Projeto de Gestão foi praticamente nula desde a sua criação, há cerca de quatro anos. Embora não se tenha utilizado metodologia adequada no presente trabalho para constatar o conhecimento da população acerca do Aqüífero Guarani, nota-se facilmente a ignorância da grande maioria das pessoas acerca do assunto. Se já é raro alguém saber o que é este

\footnotetext{
14 Princípio 15 da Eco 92: Prevê que a ausência de certeza científica absoluta não deve servir de pretexto para procrastinar a adoção de medidas efetivas visando a evitar a degradação do meio ambiente. Vale dizer, nas palavras de MILARÉ, que "a incerteza científica milita em favor do ambiente, carregando-se ao interessado o ônus de provar que as intervenções pretendidas não trarão conseqüências indesejadas ao meio considerado." (Édis Milaré, Direito do Ambiente. p. 103).

${ }^{15}$ Revista Consultor Jurídico, 1ำ de setembro de 2003.

16 Ibidem.
} 
aqüífero, menos conhecido ainda é o projeto que lhe está sendo implementado, apesar de sua importância e complexidade.

Tal desconhecimento é um solo fértil para a despolitização do debate sobre a mais importante reserva de água doce do mundo. O que vem ocorrendo, efetivamente, é a tecnização da discussão, causando uma exclusão ainda maior da população, no que respeita à gestão dos recursos do Aqüífero.

É de se destacar, nesse sentido, algumas tentativas de se ampliar o debate sobre o Aqüífero e o Projeto, como se fez no Fórum Social do Aqüífero Guarani, realizado em Araraquara/SP, nos dias 9 a 15 de novembro de 2003, no qual foram realizadas atividades de educação ambiental para a mobilização comunitária, além de debates, palestras e conferências, programação esta voltada a delegações do Brasil, Argentina, Paraguai e Uruguai. Um dos organizadores deste Fórum, o coordenador geral do movimento Grito das Águas, Leonardo MORELI, diante da assertiva de que as informações obtidas em pesquisas vinculadas ao Projeto não estarão disponíveis aos brasileiros, enfatiza:

"Esse é um dos motivos pelo qual entendemos ser urgente a mobilização social em defesa das águas para garantirmos um futuro de paz para as presentes e futuras gerações. Temos que lutar pela erradicação das áreas contaminadas e pelo exercício do direito ambiental. $\mathrm{A}$ água como valor social, patrimônio da humanidade e direito universal é fundamental a todo e qualquer ciclo da vida. É importante ter consciência de que as nações ricas e poderosas não irão se submeter a países de terceiro mundo, nem pouparão seu poder para se apropriar do que é nosso através da violência e de influências econômicas. A situação é clara, e é preciso fazer algo antes que seja tarde. ${ }^{17,}$

Tal gestão deveria, de fato, ter um caráter eminentemente público, haja vista que a água configura-se como um direito humano fundamental, extremamente atrelado ao direito à vida. Entra em cena, assim, uma das mais importantes discussões da atualidade no cenário mundial, que é a mercantilização e a privatização da água. Em outras palavras, a falta de um profundo debate com a participação da sociedade faz com que esses fenômenos, da mercantilização e apropriação privada da água, passem a ser considerados naturais pelo senso comum.

17 Aqüífero Guarani é tema de fórum social em Araraquara/SP. Disponível em: <www.guiaparana.com.br/amb/fguarani> Acesso em: 20 de outubro de 2.003 . 


\subsubsection{Mercantilização e Privatização de Recursos Hídricos no Mundo e no Brasil}

De fato, o princípio da água como bem econômico ${ }^{18}$, importante princípio amplamente difundido atualmente, assim como outras concepções, idéias e inventos humanos, possui suas vantagens e desvantagens. Nas palavras de GRANZIERA, "é uma faca de dois gumes". ${ }^{19}$

A principal vantagem apontada seria um uso mais racional da água, obrigando os grandes usuários a prestarem uma contrapartida pelo uso de tão importante recurso natural. Já as desvantagens podem ser inúmeras, se o princípio não tiver uma adequada aplicação, com vistas ao bem-estar público. $\mathrm{Na}$ agenda política mundial, porém, o discurso da água como bem dotado de valor econômico parece estar mais associada a interesses financeiros que à necessidade de prover seu acesso aos mais necessitados.

(...) as discussões, na atualidade, estão centradas no reconhecimento do valor econômico da água e não em sua dimensão social. Nos últimos eventos internacionais, organizados para abordar a crise mundial da água, ficou nítida a polarização nesses debates; de um lado, se alinham os interesses do capital financeiro internacional e das grandes empresas multinacionais, que exploram a água, insistindo no reconhecimento da água como um bem econômico e reivindicando que sua administração seja confiada ao mercado; de outro lado, organizações sociais se posicionam contrárias à privatização dos serviços de água, postulando o reconhecimento do direito à água e a democratização da sua gestão. ${ }^{20}$

Lembre-se que o fenômeno de minimização do Estado, aquele que diminui a atuação estatal na economia e no direcionamento dos bens e serviços essenciais à manutenção da sociedade, sob o principal argumento de que seria o Estado ineficaz para garantir o que é proposto, já é comum em quase todo o mundo, inclusive no Brasil. Dessa forma, a minimização e desregulamentação do Estado já ocorreram

${ }^{18}$ A água para Economia é, hoje, um recurso limitado. Por este motivo, passou-se a atribuir-lhe um "valor econômico", pois lida a Economia com recursos escassos, variando o valor a estes atribuído de acordo com a sua maior ou menor disponibilidade. No Brasil, a principal norma a tratar do assunto é a Lei 9.433/97 Política Nacional de Recursos Hídricos.

${ }^{19}$ GRANZIERA, Maria Luiza Machado. Direito de águas e meio ambiente. São Paulo: Ícone, 1993. p. 35.

20 IRIGARAY, Carlos Teodoro José Hugueney. Água: um direito fundamental ou uma mercadoria? In: BENJAMIN, Antonio Herman (Org.). Direito, água e vida. São Paulo: Imprensa Oficial, 2.003. 1 v. p. $385 / 386$. 
com diversos serviços públicos essenciais, como a geração e distribuição de energia elétrica, telecomunicações, entre outros.

A mercantilização da água, assim como a privatização dos serviços de distribuição, se insere num quadro de supremacia do capitalismo financeiro internacional que vê a água, no século XXI, como um "negócio" semelhante ao que foi o petróleo no século XX. ${ }^{21}$

Com efeito, vem o Banco Mundial, principal patrocinador do Projeto Aqüífero Guarani, junto com outros organismos financeiros internacionais, "orientando" os países endividados a privatizarem seus serviços, argumentando que o setor nesses países é supostamente incompetente. Tal afirmação está de acordo com o Relatório "Água com justiça para todos: Resistência mundial e local contra o controle empresarial e a mercantilização da água"22, divulgado pela organização "Friends of the Earth International". Conta ainda tal relatório que os empréstimos financeiros a alguns países empobrecidos estão sendo condicionados à desregulação dos serviços de água e à abertura desses setores aos investimentos privados. Exemplos são Moçambique, Benim, Nigéria, Gana, Ruanda, Honduras, lêmen, Tanzânia, Camarões e Quênia. Irigaray, diante desse quadro, afirma: "Em lugar de mitigar a pobreza, a privatização significa que as famílias empobrecidas deixam de dispor economicamente da possibilidade de acessar a água". ${ }^{23}$

Daí a insustentabilidade dos mercados de água, pois os interesses do capital financeiro internacional, no que tange à gestão das águas, apontam para a desconstrução dos Estados e para um gerenciamento econômico e antidemocrático, ou simbolicamente participativo, a ser implementado com base nos mercados de direito de água, ampliando os conflitos e a exclusão.

Ademais, a mercantilização da água é capaz de impactar também o meio ambiente, de forma negativa, já que a gestão se encontraria, por óbvio, voltada à maximização de lucros, e não à proteção do ambiente. O ciclo hidrológico se vê, assim, ameaçado, pois o que passa a definir a quantidade de água a ser captada é

\footnotetext{
21 Ibidem. p. 390.

22 Disponível em: <http://www.foei.org>. Acesso em: 25 de novembro de 2.003.

23 IRIGARAY, op.cit. p. 390/391.
} 
secundariamente a disponibilidade do corpo hídrico, e primeiramente o interesse econômico. ${ }^{24}$

A desestruturação estatal e os negativos impactos ambientais culminam, então, na maior razão da insustentabilidade dos mercados de água, que é a exclusão social. Realmente, é por demais perigoso à coletividade submeter às leis de mercado um bem tão indispensável à vida, o que dificilmente se dará sem agravar os problemas de exclusão e, por conseqüência, de saúde pública, visto que o acesso à água de qualidade é pressuposto do direito à saúde, sem esquecer que grande parte das doenças verificadas nos países pobres decorre da falta de distribuição de água em quantidade e qualidade adequadas. ${ }^{25}$

No Chile, onde a legislação sobre a água é extremamente liberal, em consonância com os princípios difundidos pelo Banco Mundial, já se criou uma nova forma de especulação, em que algumas companhias mineradoras conseguem controlar o mercado de água e simular situações de falta de água, a fim de aumentar os preços. ${ }^{26}$

Nos países pobres, onde os serviços de água foram privatizados, ocorreu substancial aumento das tarifas de água. Em Gana as condições impostas pelo Banco Mundial e o FMI determinaram um aumento de $95 \%$ nas tarifas de água; Em Cochabamba (Bolívia) as tarifas ascenderam ao ponto de consumir $25 \%$ da receita familiar de certos residentes empobrecidos, à semelhança do que aconteceu na Índia. ${ }^{27}$

O supracitado autor afirma ainda que a mercantilização da água tem tido considerável apoio da Organização das Nações Unidas - ONU, sob o recorrente argumento do "estrangulamento de caixa" dos governos e da necessidade de pesados investimentos, a fim de recomendar a inserção de empresas privadas no "mercado da água": "Nos Fóruns Mundiais e inúmeras conferências realizadas, o reconhecimento da necessidade de se assegurar o direito de acesso à parcela da população empobrecida vem sempre associado à tônica de que a iniciativa privada deve ser inserida nessa tarefa". ${ }^{28}$

\footnotetext{
${ }^{24}$ Ibidem. p. 392.

25 Ibidem. p. 392.

26 Ibidem. p. 393.

27 Ibidem. p. 393.

28 Ibidem. p. 391.
} 
Ora, a idéia de que o mercado otimizará o uso da água, provendo sua distribuição a um custo menor e com mais eficiência, além de simplista baseia-se em escolha puramente ideológica. Nessa concepção, o mercado se sobrepõe aos demais mecanismos (regulamentação política, cooperação ou solidariedade) no gerenciamento e distribuição ótima dos recursos naturais, ignorando assim o fato de que a água e o ar são recursos ímpares, posto que essenciais e insubstituíveis, sendo seu acesso um direito fundamental que deve ser concretizado. ${ }^{29}$

No Brasil, a Política Nacional de Recursos Hídricos, Lei 9.433/97, com firmes bases na Constituição Federal, impõe uma forte barreira ao fenômeno, já observado em outros países, da exploração privada da água e recursos hídricos, ao enunciar princípios (e com isso dirigir outras normas) como o de que a água é um bem de domínio público, que o uso prioritário em situações de escassez da mesma é para consumo humano e dessedentação de animais, bem como o de que sua gestão deve ser descentralizada e contar com a participação do Poder Público, dos usuários e das comunidades.

Por outro lado, prevê o polêmico princípio de que a água é um recurso natural dotado de valor econômico, o que, diante da prevalecente ordem econômica mundial, pode facilmente ser deturpado, desviando-o de sua intenção fundamental, que seria a racionalização do uso da água, e comprometendo-o com outros interesses que não os da coletividade.

A Política Nacional de Recursos Hídricos prevê, ainda, uma estrutura institucional voltada à participação popular. Todavia, claramente, a gestão dos recursos hídricos no Brasil vem se esquivando de uma efetiva participação da coletividade.

A sociedade civil, cuja participação está limitada por arranjos institucionais, não encontra espaço para se integrar efetivamente na formulação da política de águas, nem tampouco para aprofundar a discussão de temas nacionalmente relevantes, contribuindo modestamente com a "legitimação" de um modelo de gestão que prioriza o reconhecimento do valor econômico da água. ${ }^{30}$

Com relação ao instituto da outorga, já tratado no item 1.6, previsto no artigo $5^{\circ}$, inciso III, bem como no artigo 11 e seguintes da Política Nacional de Recursos

\footnotetext{
29 Ibidem. p. 395.

30 Ibidem. p. 395/396.
} 
Hídricos, ele está posto de forma que não seja possível a alienação dos recursos hídricos, além de existirem regras para sua imediata suspensão (artigo 15). Tratouse de regulamentar o uso dos recursos hídricos brasileiros sem que o Estado perca seu domínio.

Ao menos teoricamente, com o ordenamento jurídico atual no Brasil, portanto, não é possível a chamada "privatização da água" nos moldes já notados em outros países.

Não obstante, anote-se que, como exposto acima, a sociedade civil não está tendo uma participação efetiva na gestão dos recursos hídricos. No caso do Aqüífero Guarani isso é ainda mais grave, por se tratar da principal reserva de água doce do mundo, sendo que, enquanto os brasileiros não demonstram o devido interesse em sua administração, diversos países estrangeiros e organismos internacionais têm procurado conhecê-lo, estudá-lo e explorá-lo.

Com efeito, os sintomas que antecederam privatizações e aberturas de mercados da água em outros países estão sendo observados no Brasil.

As denúncias já não são poucas no que se refere à "compra" ou a tentativas de "apropriação" do Aqüífero Guarani. Ana Maria PRIMAVESI, uma das maiores autoridades sobre Agroecologia da América latina, autora de diversas obras e bastante requisitada no meio acadêmico para proferir palestras, em recente entrevista $^{31}$, frente a questionamento referente à ingerência dos países ricos sobre as riquezas naturais brasileiras, ou seja, se esses países estariam mesmo interessados em preservar nossos recursos, ou se isso seria mais um instrumento de domínio, assinalou: "Só querem preservar os recursos do Brasil, porque eles não conservam os deles. É o único país onde eles esperam ainda poder entrar. O que atrai mesmo são as riquezas minerais do solo brasileiro". Após, perguntada se uma dessas grandes riquezas atuais seria a água, ainda abundante no País, afirmou: "Esses países já estão tentando comprar o Aqüífero Guarani, um lençol freático subterrâneo que ocupa boa parte do território nacional, para depois vender água para os brasileiros. É tudo por dinheiro".

Ademais, quanto à caracterização da água como direito fundamental, há que se lembrar que isso se deu através de uma evolução histórica, o que confirma o

${ }^{31}$ Entrevista concedida à Revista Safra, $n^{\circ} 6,2.001$. D isponível em: <http://www.revistasafra.com.br/ 2001-06/ Entrevista.htm>. Acesso em 19 de julho de 2.004. 
entendimento de que não há qualquer segurança quanto à imutabilidade de qualquer estatuto jurídico. Diante disso, não se pode negar a importância do envolvimento da sociedade na elaboração das regras que irão regulá-la e na administração dos bens que são de seu interesse, sob pena de o mundo jurídico e o mundo factual/sociedade encontrarem-se em total desconexão, em prejuízo da sociedade.

\subsubsection{Gestão Participativa dos Recursos Hídricos}

Frente aos modelos de gestão da água implementados até hoje, conclui-se que não conseguiram alcançar a desejável sustentabilidade em sua utilização, causando assim sua deterioração em detrimento de boa parte da população atual e futura.

Impõe-se, diante disso, uma nova forma de gerir a água e os recursos hídricos; um novo sistema de gerenciamento, cuja aplicação urge no caso do Sistema Aqüífero Guarani, em que a água seja efetivamente reconhecida como um direito fundamental, e ao Estado seja conferido o papel de guardião de tão valioso bem, gerindo-o de forma democrática, ampliando quantitativa e qualitativamente a participação pública em tal processo.

A participação comunitária na tutela do ambiente encontra-se ainda em processo de evolução. No entanto, a Constituição de 1988, visando a necessidade de os cidadãos articularem seus desejos e idéias e de tomarem parte ativa nas decisões que lhes interessam, foi pródiga no realce dessas conquistas ao consagrar o meio ambiente ecologicamente equilibrado como direito constitucional, bem como, principalmente, ao impor à coletividade, e não só ao Estado, o dever de preservá-lo e protegê-lo. ${ }^{32}$

Sobre essa forma democrática de gerenciamento, Irigaray, um de seus fomentadores, afirma:

Não se pode ignorar as dificuldades inerentes a essa tarefa, na medida em que a água possui valores socialmente distintos, e seu manejo envolve interesses freqüentemente divergentes; contudo esse mesmo argumento reforça a necessidade de um comprometimento do sistema político com respeito a essa pluralidade de interesses,

32 MILARÉ, op.cit. p. 245. 
subtraindo esse patrimônio comum de uma lógica mercantilista, que conduz à livre disposição e aos abusos característicos da autonomia jurídica individual. ${ }^{33}$

Vale lembrar que a concretização da democracia não é possível sem a efetivação dos direitos fundamentais. Nessa esteira, pressupõe-se o envolvimento da comunidade na tarefa que Ihe foi constitucionalmente atribuída, juntamente com o poder público, qual seja a de defesa e preservação desse macrobem para as presentes e futuras gerações.

Ressalte-se que, embora a legislação atual contenha inegáveis avanços no que tange à gestão participativa, esta não se faz por mera proclamação, carecendo ainda de arranjos institucionais que possam funcionar independentemente de boa ou má vontade política, e com vistas à capacidade dos corpos hídricos, a fim de se manter o equilíbrio ecológico. ${ }^{34}$

A concretização do fundamental direito à água implica incentivar a consciência e compromisso tanto de cidadãos como de políticos com uma gestão participativa, eqüitativa e solidária, com o escopo de garantir os usos múltiplos da água, o acesso geral e a provisão suficiente à dignidade da pessoa humana. $\mathrm{Na}$ concretização desse direito, entretanto, muita coisa ainda está por fazer, exigindo criatividade e, acima de tudo, democracia.

\section{CONCLUSÃO}

A água em si, considerada como recurso hídrico, é, inegavelmente, pressuposto para existência de vida na Terra e imprescindível para a existência digna do ser humano, consagrando-se seu acesso, então, como um direito humano fundamental, no mesmo patamar do meio ambiente equilibrado.

Para a proteção de tais direitos, quais sejam, o acesso à água e o equilíbrio ambiental, necessário se faz a análise dos recursos naturais através de uma visão sistêmica e interativa. A água, por sua vez, enquanto parte integrante de praticamente todos os processos e ciclos naturais, não se esquiva de tal visão, devendo em sua gestão e proteção ser considerado todo o seu ciclo.

\footnotetext{
33 IRIGARAY, op.cit. p. 397.
} 
No Brasil, as águas subterrâneas, todas aquelas situadas abaixo da superfície da Terra, são alvo de incidência de regras jurídicas dos mais diversos ramos do Direito, o que, todavia, não é o suficiente para sua devida proteção e para a efetivação do fundamental direito da população de acesso à água de boa qualidade, visto que tais problemas transcendem a esfera jurídica, enraizando-se na cultura popular e na errada forma de gestão dos recursos públicos.

Ainda assim, há que se conceder o devido mérito a alguns dos instrumentos legislativos hoje vigentes, como a Constituição Federal e a Política Nacional de Recursos Hídricos, as quais, sem dúvida, devem dirigir todas as demais normas relativas à água, posto que portadoras de modernos institutos protetivos do meio ambiente e dedicados à valorização da água como direito fundamental. Assim como as normas nacionais, quaisquer acordos internacionais devem também se coadunar com aqueles instrumentos citados.

A fim de avançar no estudo do Aqüífero Guarani, cabe notar que este é um sistema de águas subterrâneas transfronteiriças, enquadrando-se, assim, em alguns conceitos elaborados em convenções internacionais. Entre estes, o que lhe confere maior proteção, e que deve, portanto, ser aplicado, é o de "bacia de drenagem internacional", pois adota a importante visão sistêmica da água ao considerar integrante da bacia todo o ciclo hidrológico.

A adoção do conceito de bacia de drenagem internacional, decorrente da observância do caráter sistemático da natureza, induz obrigatoriamente a uma mudança no conceito de soberania de Estado, no sentido de relativizá-la em prol do ambiente.

Sem qualquer dúvida, o Aqüífero Guarani é capaz de se constituir no principal trunfo deste pequeno bloco econômico, o Mercosul, já que guarda um grande volume do que tende a ser um dos principais bens econômicos do mundo.

Com efeito, o Aqǘf́rero Guarani é o maior reservatório de água subterrânea do mundo até hoje descoberto, abrangendo quatro países latino-americanos, Brasil, Argentina, Paraguai e Uruguai. Embora suas águas figurem entre as mais puras do planeta, sua integridade encontra-se ameaçada, seja pelo desmatamento irracional das matas ciliares de suas áreas de recarga, seja pela ação dos mais diversos

34 Ibidem. p. 398. 
poluentes que se infiltram no solo e atingem suas águas, como agrotóxicos e chorume de lixões.

Tendo em vista a extrema dificuldade em despoluir aqüíferos de águas subterrâneas, a melhor forma de proteger o Aqüífero Guarani é através de ações preventivas, sendo que sua contaminação, dadas as suas proporções, seria um dos maiores desastres ecológicos de todo o mundo.

Pelo seu caráter transfronteiriço, é o Aqüífero Guarani merecedor de proteção internacional, o que se faz essencialmente por regras do Direito Internacional do Meio Ambiente, ramo do Direito com crescente autonomia. Relevante instrumento deste ramo do Direito, aplicável ao Guarani, é o Projeto de Proteção Ambiental e Gestão Sustentável Integrada do Sistema Aqüífero Guarani.

Quanto a este projeto, cujo objetivo oficial é a formulação de um modelo de gestão dos recursos hídricos do Sistema Aqüífero Guarani, cabe ressaltar sua importância, e, não obstante, seus pontos polêmicos, pois ao mesmo tempo em que se prevêem diversas formas de proteção da qualidade das águas do Aqüífero, há diversos organismos internacionais envolvidos no Projeto, sendo que muitos de seus interesses encontram-se ainda encobertos. Muitas são as vozes a denunciar interesses exclusivamente financeiros por parte de tais organismos, sendo que seria esta a principal razão da exclusão de uma efetiva participação popular nas decisões referentes à gestão do Sistema Aqüífero Guarani.

A dotação de valor econômico à água é um importante princípio aplicável com vistas a um uso mais racional da mesma, mas que é também, como qualquer idéia, doutrina ou invento humano, passível de ser utilizado de forma negativa, em detrimento de alguns (muitos) e benefício de outros (poucos), no contexto da atual ordem econômica mundial. O problema apontado é que o princípio da água como bem econômico vem sendo associado no mundo inteiro a interesses financeiros, e não à necessidade de prover seu acesso aos mais necessitados. A mercantilização e privatização da água são fenômenos que vêm ocorrendo em diversos países empobrecidos, o que tem resultado num aumento da miséria da população destes países.

No Brasil, os citados fenômenos não parecem ser tão fáceis de ocorrerem, tendo em vista algumas barreiras impostas pelo ordenamento jurídico. Todavia, há que se lembrar que em nenhum lugar existe total segurança quanto à imutabilidade 
dos estatutos jurídicos, sendo por isso de suma importância a ativa participação social na elaboração das leis que the irão reger e na gestão das coisas públicas, o que, infelizmente, não vem ocorrendo.

Desponta como solução dos problemas elencados no presente trabalho a participação social na gestão dos recursos hídricos, ou gestão participativa dos recursos hídricos, constitucionalmente prevista, porém ainda carecedora de arranjos institucionais que the permitam funcionar de forma independente.

Tal participação, cuja implantação faz-se necessária no caso do Aqüífero Guarani, seria o corolário de uma nova forma de gestão de recursos hídricos, marcada pela conscientização e pelo compromisso dos cidadãos e do sistema político, com vistas à concretização do direito fundamental à água de boa qualidade.

\section{REFERÊNCIAS}

ANTUNES, Paulo de Bessa. Direito Ambiental. 6. ed. Rio de Janeiro: Lúmen Júris, 2.002.

BENJAMIN, Antonio Herman (Org.). Direito, água e vida. São Paulo: Imprensa Oficial, 2.003. 1 v.

BENJAMIN, Antonio Herman (Org.). Direito, água e vida. São Paulo: Imprensa Oficial, 2.003. 2 v.

BUGIERMAN, Denis Russo. Tem uma esponja aqui dentro. Super Interessante, ano $13, n^{\circ} 7$. São Paulo: Abril, 1.999. p. 62-67.

CAPRA, Fritjof. O ponto de mutação. São Paulo: Cultrix. 12 ed. 1.992.

CASARINI, Dorothy C. P. Controle e prevenção da poluição de aqüíferos. In: Saneamento Ambiental. v. 57, mai/jun, 1.999. p. 37.

CONDESSO, Fernando dos Reis. Direito do ambiente. Coimbra: Livraria Almedina, 2.001.

FREITAS, Vladimir Passos de. Águas: Aspectos jurídicos e ambientais. 2. ed. São Paulo: Juruá, 2.002 .

GRAF, A. C. B. QUADROS DA SILVA, F. Q. PACIORNIK, J. L. RIBEIRO, J. MALUCELLI, M. BRUNONI, N. Águas: aspectos jurídicos e ambientais. 2. ed. Curitiba: Juruá, 2002.

GRANZIERA, Maria Luiza Machado. Direito de águas e meio ambiente. São Paulo: Ícone, 1993.

GRANZIERA, Maria Luiza Machado. Direito de águas: disciplina jurídica das águas doces. São Paulo: Atlas, 2.001.

HEATH, Ralph C. Hidrologia básica de água subterrânea. 
INSTITUTO SERRANO NEVES. Riscos de contaminação na maior reserva de água do mundo. Disponível em: <http://www.jornalexpress.com.br/noticias/detalhes.php?id_jornal=8341\&id_noticia $=192>$ Acesso em: 19 de julho de 2.004 .

MACHADO, Paulo Afonso Leme. Curso de direito ambiental brasileiro. 9. ed. São Paulo: Malheiros, 2.001.

MEIRELLES, Hely Lopes. Direito administrativo brasileiro. 18. ed. São Paulo: Malheiros, 1.993.

MILARÉ, Edis. Direito do ambiente: doutrina, prática, jurisprudência, glossário. 2. ed. São Paulo: Revista dos Tribunais, 2001.

RAFFESTIN, Claude. Por uma geografia do poder. São Paulo: Ática, 1.993.

REBOUÇAS, Aldo da Cunha; BRAGA, Benedito; TUNDISI, José Galizia (Org.). Águas doces no Brasil: capital ecológico, uso e conservação. São Paulo: Escrituras, 1.999.

REBOUÇAS, Aldo da Cunha. 1976. Recursos hídricos subterrâneos da bacia do Paraná: análise da pré-viabilidade. Tese de Livre Docência. Universidade de São Paulo.

ROCHA, Gerôncio Albuquerque. O grande manancial do Cone Sul. In: Revista Estudos Avançados, n³0. São Paulo: Instituto de Estudos Avançados/US P, 1.997. 11v.

SILVA, José Afonso da. Direito ambiental constitucional. 4. ed. São Paulo: Malheiros, 2002.

SOARES, Guido Fernando Silva. Direito internacional do meio ambiente: emergência, obrigações e responsabilidades. 2. ed. São Paulo: Atlas, 2003.

SOARES, Guido Fernando Silva. Curso de direito internacional público. 2. ed. São Paulo, 2.004. 1 v.

VIANNA, Pedro Costa Guedes. Gestión internacional de recursos hídricos: el caso del acuífero gigante del MERCOSUR. Barcelona: Scripta Nova - Revista Electrónica de Geografia y Ciencias Sociales, n45 (15), ago, 1.999. Disponível em: <h ttp://www.ub.es/geocrit/sn-45-15.htm>

VICTORIO, Iço. Taquari: o que a agropecuária fez com um rio. In: Revista JB Ecológico. ano 3, n. 28. p. 30-35. 6 maio, 2.004. 